\title{
Seismic Retrofitting of Low Strength Unreinforced Masonry Non-engineered School Buildings
}

\author{
J. K. Bothara ${ }^{1}$, B. Pandey ${ }^{2}$ and R. Guragain ${ }^{2}$
}

\begin{abstract}
Schools in Nepal, both their buildings and its occupants face extreme risk from earthquakes because of highly vulnerable building stock and high occupancy in it. Further, schools house an entire generation and a community's future so these need special attention. Loss suffered by a community in collapse of a school is psychologically much greater than any other community building.

In 1988 the Udaypur earthquake, which measured 6.6 on the Richter scale, about 950 school buildings incurred damage of different degrees spanning between damage to collapse. A study completed by the Kathmandu Valley Earthquake Risk Management Project in $2000 \mathrm{AD}$, to explore the seismic vulnerability of school buildings and possible intervention options in Kathmandu Valley, showed a grim situation. This paper explores the methods that were implemented for strengthening existing low strength unreinforced masonry school buildings. A basic emphasis was placed on economic affordability, technical implementation and its adoptability by local craftsmen. The retrofitting design was based on identification of deficiencies, the most critical failure mechanisms, and simple calculations.
\end{abstract}

\section{INTRODUCTION}

Most of the buildings in Nepal are constructed by the local community with the help of local craftsmen. The community relies on craftsmen for organizational and technical input, although most of them have no formal training. Although partial technical inputs by engineers in the form of planning, design and construction supervision is not uncommon in urban areas, it does not necessarily incorporate seismic safety in the buildings as seismic design is not a part of the overall practice. New buildings in Nepal are built by convention, rather than being specifically designed. The overall process is very informal to the extent that technically ignorant owners often make decisions on structural elements.

Buildings in Nepal can be broadly divided in two groups based on construction materials: i) those built with traditional local materials such as adobe (unfired brick) or fired brick, stone, mud, timber, bamboo etc; and ii) those built with modern imported materials such as cement, cement concrete, reinforcement, and corrugated iron sheets etc. Construction of buildings in Nepal is largely dictated by the availability of construction materials and labour skills in the immediate locality. However, use of modern materials is being used more frequently as they become more affordable and there is improved accessibility to the market and information. Furthermore, it is common to periodically extend existing buildings, so material and technology used in the construction vary both horizontally and vertically.
Construction of an upper storey and with brick laid in cement mortar above a lower storey constructed with brick and mud mortar is not an infrequent situation.

It is not practically possible to strengthen such buildings up to code requirements at reasonable cost because of inherent weaknesses in the materials, such as the lack of tensile strength and very low shear strength, and other construction deficiencies, such as weak connections and substandard construction. Nevertheless, the seismic risk to the occupants can be significantly reduced at an affordable cost by any positive intervention aimed to increase the structural integrity. Such interventions may be possible by intuitively trying to avoid the damage mechanisms observed in past earthquakes in similar buildings by performing simple calculations.

A recent study by the National Society for Earthquake Technology-Nepal (NSET, 2000) showed that $90 \%$ of the school buildings in Kathmandu Valley are made of unreinforced masonry. Out of these, $70 \%$ are constructed of adobe, stone or fired brick in mud mortar (referred here after as URM) with either timber floor/roof or in-situ concrete slabs. During the 6.4 Richter scale Chamoli Earthquake, such URM buildings located as far as $200 \mathrm{~km}$ from the epicenter collapsed (NSET 1999). A seismic scenario (NSET, 2000) developed by the Kathmandu Valley Earthquake Risk Management Project (KVERMP) and implemented by NSET for the assessment of seismic vulnerability of school

\footnotetext{
' Dept. of Civil Engineering, University of Canterbury, Christchurch, NZ, Team member KVERMP, ikb46@student.canterbury.ac.nz

${ }^{2}$ National Society of Earthquake Technology-Nepal, P. No.: 977-01-4474192, nset@nset.org.np
} 
buildings, showed that if the 8.4 Richter scale 1934 NepalBihar Earthquake was to strike today, almost all school buildings built of URM in the Kathmandu Valley would collapse. As expected, such buildings do not meet any of the current seismic design requirements and pose high levels of seismic risk.

Schools are the focal point of any community and this is a matter of concern for all. Any activity in schools has far reaching effects. By raising awareness in schools, the entire community is reached because lessons trickle down to parents, relatives, and friends. Seeing the high potential for schools to introduce seismic protection at the community level and train craftsman, NSET-Nepal decided to conduct a program to strengthen existing school buildings and promote more earthquake resilient school buildings. The program incorporated strengthening of structural as well as nonstructural components for seismic safety.

This paper summarizes the strategies, assumptions and philosophy behind the intervention for seismic safety of school buildings in the Kathmandu Valley. It also describes cost-effective and affordable strengthening schemes that are suitable for URM buildings. It documents the first-hand experience the authors gained in implementing the low-cost strengthening scheme on a few selected URM school buildings in the Kathmandu Valley. Although several URM buildings may have been retrofitted using similar techniques, the authors are unaware of those details being published and therefore being accessible to the international professional arena. The intent of this paper is to convey those yetunnoticed issues pertinent to low strength URM buildings.

\section{UNREINFORCED MASONRY BUILDINGS}

Aiming to raise seismic awareness in communities and to transfer the technology to the local craftsmen, NSET-Nepal has been retrofitting a few buildings each year since 1999 in different parts of the Kathmandu Valley. Most of these buildings were constructed of low strength unreinforced masonry during the last few decades. Some of those school buildings were originally built for other purposes (such as residential, community etc) and were later changed to schools. To accommodate the changed functional requirements, the room sizes were often readjusted and openings relocated. Many had a new story added to meet the increased space demand.

The retrofitted buildings were two-storey buildings of load bearing type with $350 \mathrm{~mm}$ thick walls in brick in mud mortar sitting on strip foundations. Due to multi-phase construction, some of the retrofitted buildings had $230 \mathrm{~mm}$ thick walls made of bricks in cement mortar in the upper storey. In some buildings, external walls of fired brick and internal walls of adobe, both in mud mortar, were also observed. Storey height of these buildings ranged between $2.4 \mathrm{~m}$ ( 8 feet) and $2.7 \mathrm{~m}$ ( 9 feet). Most of the school buildings were symmetrical in plan and elevation. The windows were small and away from the wall junctions. The rooms were small and walls covered more than $15 \%$ of the plinth area (foot-print of the building). One of the retrofitted two-storey school buildings is shown in Figure 1.

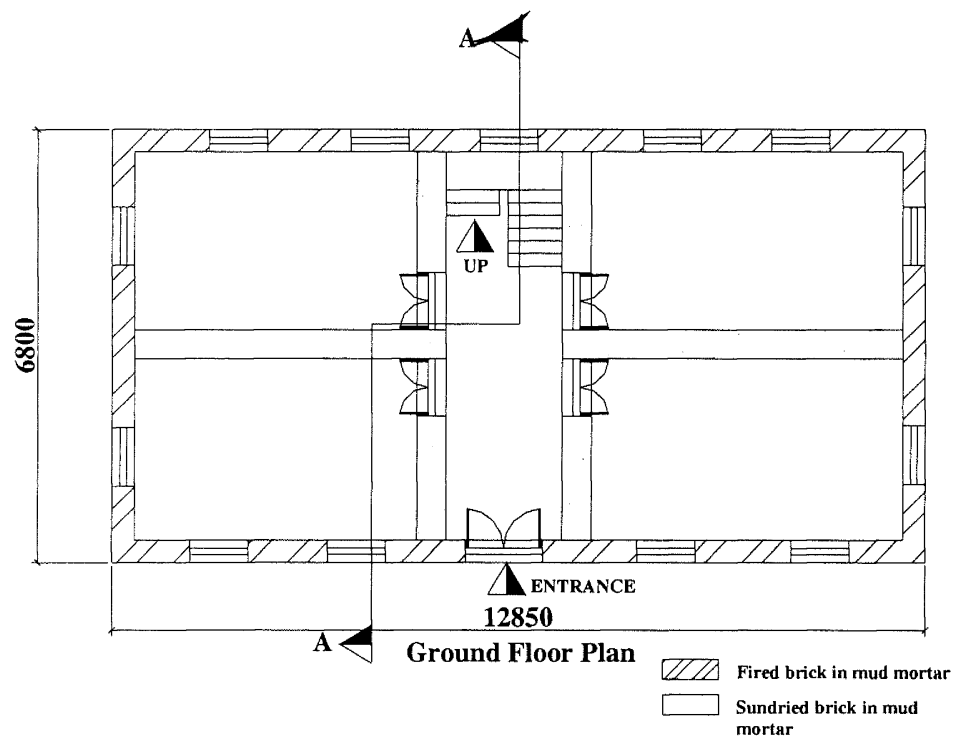

a) Plan

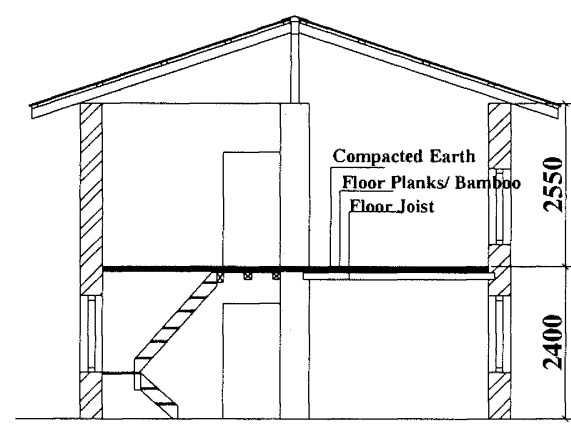

Section A-A

b) Section

Figure 1: Typical layout of existing school buildings (before intervention) 


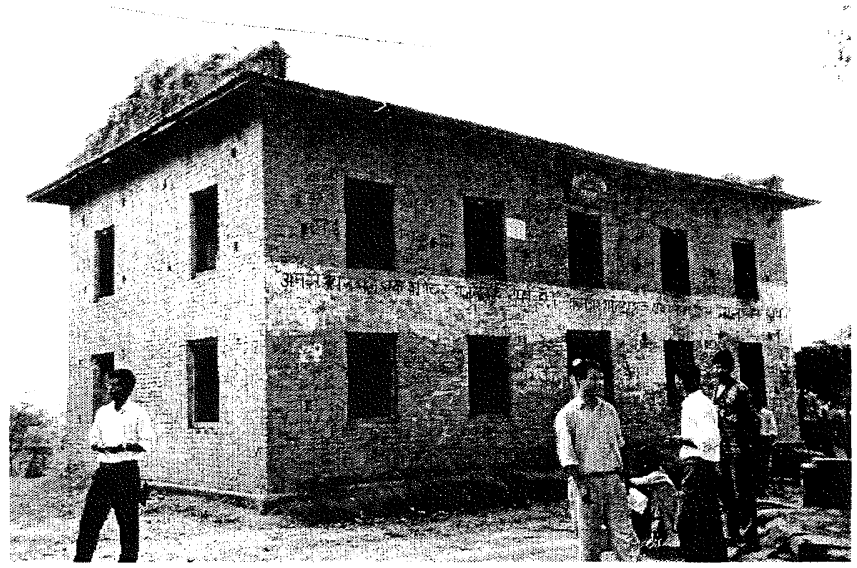

c) A general photographic view

Figure I continued: Typical layout of existing school buildings (before intervention)

The major problem with those retrofitted URM buildings was lack of connections between different structural components. The orthogonal walls were connected either by vertical joints or the orthogonal walls were not constructed simultaneously resulting in a poor anchorage (Figure 2). The bricks were laid in mud mortar, which has a low shear strength and almost no tensile strength. Flexible floors were mostly constructed of soil laid on timber planks or bamboo strips supported on timber joists. The depth of the soil topping on floors was typically $75 \mathrm{~mm}$. The floor joists were also not tied up to the walls. Planks were just placed on the joists without any nailing. The roofs were typically constructed of timber with corrugated iron sheets. As in the floors, the components of the timber structure supporting the roofing material may not be firmly tied with each other and with the walls. The gable walls were not tied to the roof structure. Hence, the buildings were more like stacked materials without interconnections.

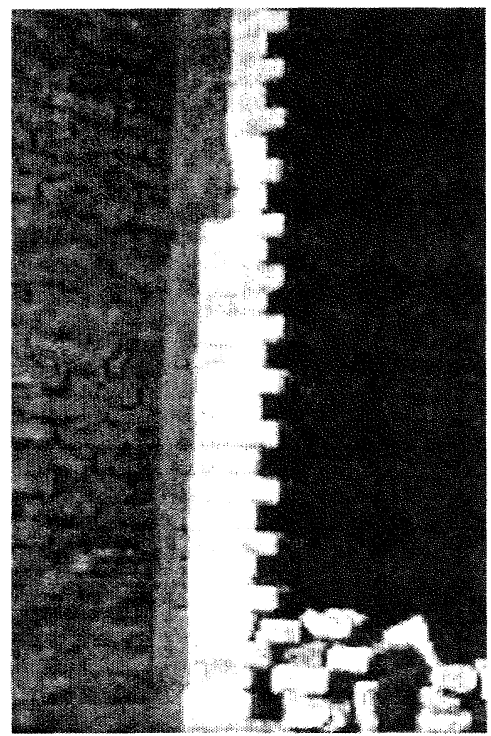

Figure 2: Toothing for wall construction

\section{POSSIBLE FAILURE MECHANISMS}

URM buildings suffered severe damage in the past earthquakes. Collapse of such buildings was rapid. Lack of integrity was the foremost cause of the initiation of damage (NSET, 1999). Damage incurred by URM buildings with flexible floors and roofs can be attributed to insufficient or total lack of in-plane stiffness of floor and roof diaphragms, inadequate anchorage between the walls, floors, and roof (Fujiwara, 1989, NSET, 1998). The damage was accentuated by inherent weaknesses of the materials. The following basic failure mechanisms can be postulated from the damage observed in URM buildings in past earthquakes:

- The "weakest link" of such buildings is the poor anchorage between different components (Doherty, 2000). Once the anchorages fail, the building loses integrity and rapidly fails.

- After a few initial shocks, the out-of-plane walls separate from the in-plane walls forming continuous vertical cracks (Lizundia, 1997, NSET, 1998). Then the isolated walls start to behave as vertical cantilevers (Figure 3). Note that this mode of failure is very rapid (Bruneau, 1994).

- In similar buildings with flexible floor/roof, the inplane walls contribute very little to the protection of the out-of-plane walls, which lead to the overall failure of the building (Karantoni, 1992a).

- Walls carrying the floor/roof suffer more damage if the shaking is normal to them unless strength of in-plane walls has been mobilized through diaphragm action (Qumaruddin, 1991).

- If in-plane walls are far apart, toppling of central part of the out-of-plane walls takes place (Figure 4).

- The in-plane walls and piers may suffer shear failure (Figure 5). The shear cracks in the piers usually initiate from the corners of the openings. In some cases sliding failure of the piers along the base may also take place. 
- Depending on the aspect ratio of the in-plane walls and piers, flexural cracks may emerge. The impact caused during subsequent excitations further impairs the bond between different brick layers which finally leads to the crumbling of the in-plane walls.

- In buildings with rigid floor/roof, failure of in-plane piers is the most common mode of failure particularly in the lower storeys. In contrast, failure of the out-ofplane walls is still possible in the top storey due mainly to acceleration amplification and low vertical load (Doherty, 2000).

- Collapse of gable walls is common as they behave as free cantilevers.

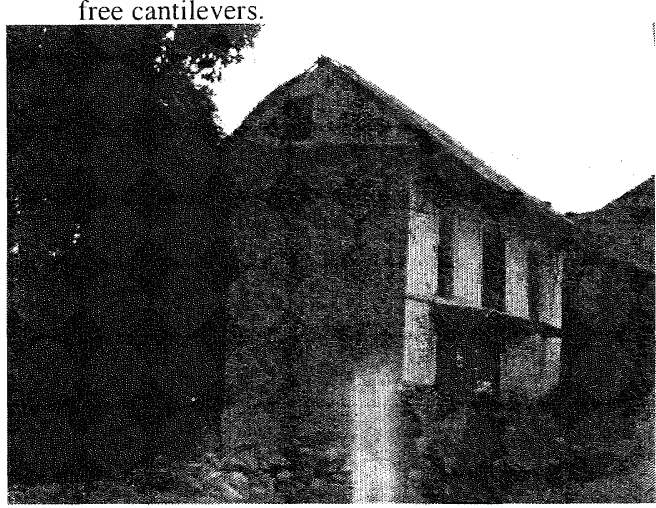

Figure 3: Shear and vertical cracking

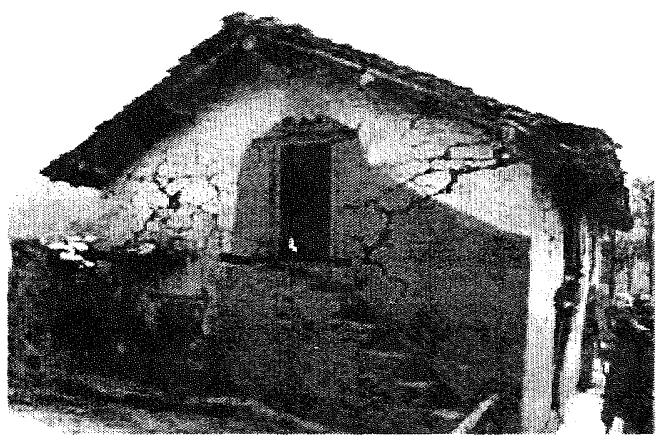

Figure 5: Shear cracking of wall piers.

\section{IMPROVEMENT OPTIONS}

The inherent weaknesses in URM school buildings could not be improved to meet the requirements of existing building design Standards at an acceptable cost in the present socioeconomic climate of Nepal. In addition, current design codes are principally for new structures and hence do not allow the flexibility required for rehabilitation work. When talking about retrofitting of existing buildings, the objective of "bringing up to code" is not relevant (Englekirk \& Sabol, 1991). Nevertheless, it is not impossible to implement strengthening schemes that try to ensure the safety of
- Floor/roof may fall down due to the lack of integrity and anchorage with the walls, (Figure 6).

- Compressive failure of piers is rare especially in rectangular block masonry building of this class.

- Building failures from excessive foundation loading are very seldom in URM. It is because the superstructure is too weak and fails long before overstressing of the foundation (NSET, 1998) in general.

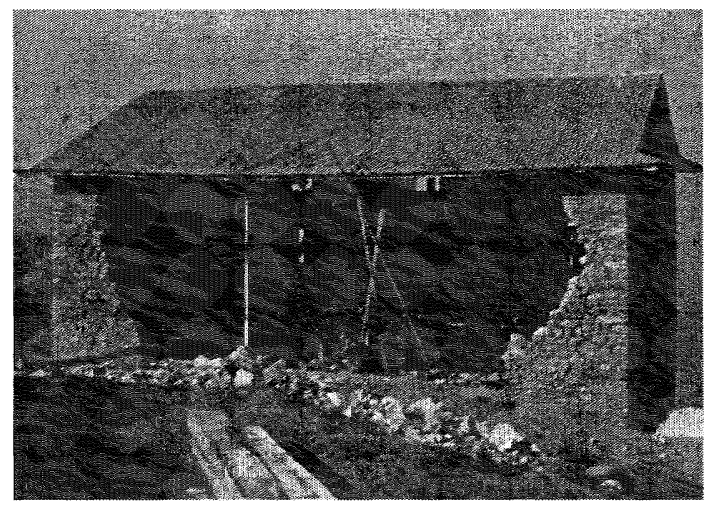

Figure 4: Out-of-plane failure of wall.

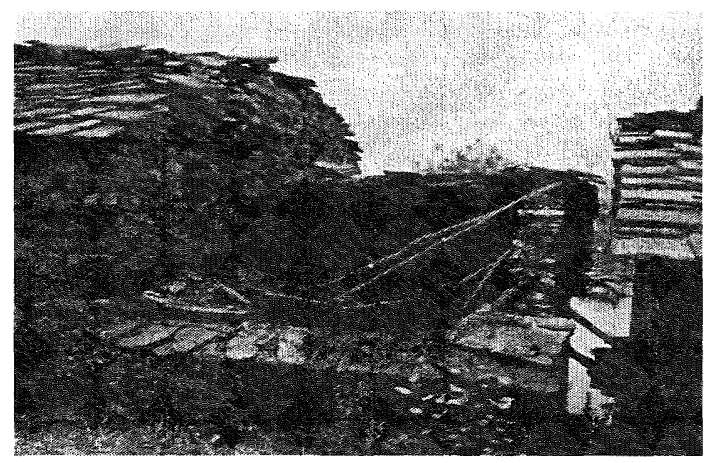

Figure 6: Collapse of roof due to lack of integrity and anchorage

occupants' lives at an acceptable cost. However, note that the level of intervention is decided based on the tradeoff between the affordability and safety. The basic goals of such interventions were that the building should be able to tolerate a low to medium level of earthquake without collapse, and it should be able to delay collapse to allow the occupants to escape during a big seismic event.

In addition the following criteria were set for the selection of the intervention scheme:

- Retention of the same structural system

- Minimum intervention to the existing structural system 
- Improvement of the integrity between the building components

- Strengthening cost to be less than $25 \%$ of the reconstruction cost

- Easily implementable by local craftsmen

- No need of any machines or plant

- Minimum time needed

- Level of opportunity for technology transfer to local craftsmen

- Improvement of structural as well as non-structural aspects
To meet the set criteria for intervention, different methods were rated qualitatively (Table 1) based on their effectiveness, adoptability, complexity, cost and time required for implementation. The qualitative assessment of some methods was taken from elsewhere (Karantoni and Ferdis 1992b, Benedetti 1998), and that of the other method is based on the engineering judgment of the authors and their colleagues.

Table 1: Comparison of retrofitting methods

\begin{tabular}{|l|l|l|l|l|l|l|l|}
\hline \multirow{2}{*}{$\begin{array}{l}\text { Strengthening } \\
\text { method }\end{array}$} & \multicolumn{9}{|c|}{ Evaluation Parameters } \\
\cline { 2 - 7 } & Cost & Time & $\begin{array}{l}\text { Complic- } \\
\text { ation }\end{array}$ & $\begin{array}{l}\text { Adoptability by } \\
\text { Local craftsman } \\
\text { and owners }\end{array}$ & $\begin{array}{l}\text { Scale of } \\
\text { intervention }\end{array}$ & $\begin{array}{l}\text { Effectiveness } \\
\text { of the system }\end{array}$ & $\begin{array}{l}\text { Suitability to the } \\
\text { existing URM } \\
\text { Buildings }\end{array}$ \\
\hline $\begin{array}{l}\text { Jacketing of } \\
\text { walls }\end{array}$ & $* * * * *$ & $* * * * *$ & $* * *$ & $* * *$ & $* * * *$ & $* * * * *$ & $* * * *$ \\
\hline $\begin{array}{l}\text { Splint and } \\
\text { bandage }\end{array}$ & $* * *$ & $* * *$ & $* * *$ & $* * * * *$ & $* * *$ & $* * * *$ & $* * * * *$ \\
\hline Bolting of walls & $* *$ & $*$ & $* *$ & $* *$ & $* *$ & $*$ & $*$ \\
\hline $\begin{array}{l}\text { Steel beam- } \\
\text { column cage }\end{array}$ & $* * * * *$ & $* * *$ & $* * * * *$ & $* * *$ & $* * *$ & $* *$ & $*$ \\
\hline $\begin{array}{l}\text { RC beam- } \\
\text { column cage }\end{array}$ & $* * * *$ & $* * *$ & $* * *$ & $* * * * *$ & $* * *$ & $* *$ & $* * *$ \\
\hline
\end{tabular}

Scale: *****: Highest, ${ }^{*}$ : Lowest.

The table shows that the bolting of the walls is the most economic and least time consuming option. However, it is not used because of concern over the loss of pre-stress in mud mortar resulting from wetting of mortar during rainy season. Furthermore, many of these buildings had workmanship problem and deteriorated wall materials, bolting of walls would not have been able to alleviate this problem. Use of steel sections is an expensive option in Nepal and furthermore it requires a high level of skill and workshop work that did not suit these non-standard buildings. As the cement, aggregate and sand are locally available so these costs are a minimum and local craftsman are used to these materials, so focus was placed on use of these materials. The splint and bandage scheme with stitching of the walls appears to be the optimal method and was therefore adopted for the Kathmandu Valley schools.

\section{ANALYSIS AND DESIGN}

Design Standard: Although the deficiencies of such URM buildings subjected to seismic excitations were assessed qualitatively as discussed earlier, it was found difficult to quantify them due to the lack of research work addressing the strength parameters and evaluation methodology. No material testing or in-situ testing was done because of resource constraints.

Dowels, anchorage system and out-of-plane stability were designed for two-thirds of the design seismic force recommended in NBC105-1994 for 300 years return period earthquakes following New Zealand recommendation (NZSEE, 1995). However, the in-plane strengthening system was designed for earthquakes with a return period of 100 years (NBCDP, 1994). A modified capacity design approach was adopted to avoid brittle failures of anchorage and out-of-plane walls more than to avoid the comparatively less brittle failure of in-plane walls. Furthermore, it was expected that the actual strength would exceed the design strength requirement because of structural redundancy and conservatism in the design.

Analysis and Design: A hierarchy of failure mechanisms was developed from damage observed in the similar buildings in past earthquakes. The load paths were identified based on which of the conceptual design of the retrofitting system was performed.

The anchorages between out-of-plane walls, in-plane walls and the floor/roof were designed with the aim that the out-of-plane walls should act as a rigid body. In the analysis, the resisting moment due to the self-weight of the out-of-plane walls and anchorages developed due to friction were ignored. For convenience, out-of-plane bending analysis of end-supported walls was performed in the line of one-way slabs spanning horizontally regardless of the nature of the end-supports. The evaluation of bending strength of the cantilever walls was based on the elastic theory of combined axial and bending stresses

The lateral load analysis for in-plane loading was based on a simple static, lumped mass system. "Pier-only" (Arya, 1987) spanning between sill and lintel level (Figure 7), analysis was conducted to assess stresses in structural components during the in-plane action. This method is similar to the storey mechanism model applied by Tomazevic (1999). Lateral load was distributed to the piers according to their stiffness based on their geometry. No specific considerations were taken for strengthening in shear. Nevertheless, the splints and bandages (discussed later) will increase shearing strength of the walls and piers. 

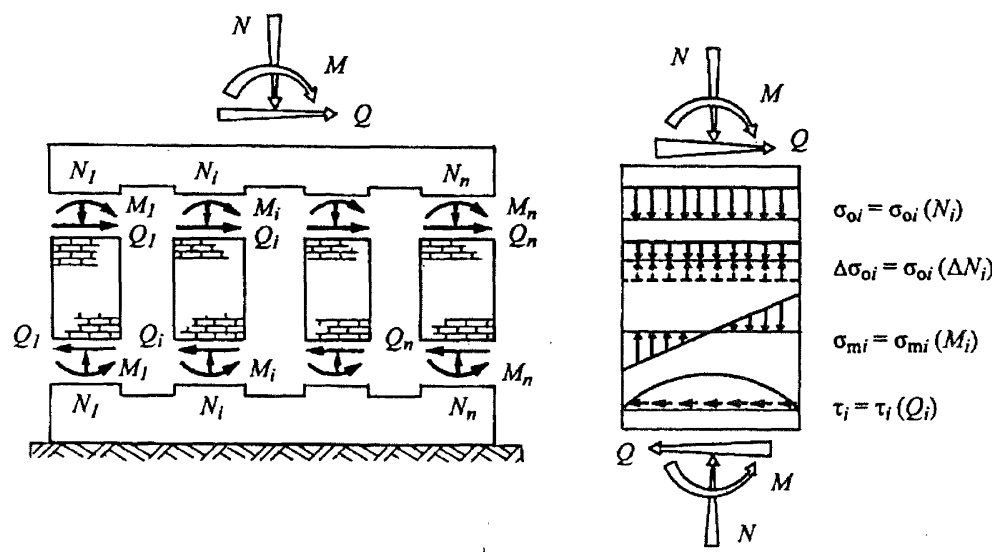

Figure 7: Forces and stresses in in-plane piers (Source: Tomazovic, 1999).

\section{SEISMIC IMPROVEMENT}

Both the structural as well as non-structural components were considered when implementing improvement measures. All the internal walls constructed in adobe were replaced with new fired brick in mud mortar walls (Figure 8). To meet the egress requirements all the doors were made to open outwards for easy exit (Figure 8) and either new easily negotiable staircases were constructed or exiting staircases were made negotiable for easy egress (Figure 8)
The basic focus of retrofitting was to enhance the integrity of the building so the building would act as a box. Site specific details were developed to enhance integrity of walls, floors, and roof structures and connections between them. The weak connections between orthogonal walls were improved at corners and $\mathrm{T}$-junctions, either by widening splints (discussed later) or by providing stitching. The stitches were provided at a spacing of about $600 \mathrm{~mm}$ (generally three stitches between floor and lintel). The stitches were placed by drilling holes in the walls first, filling the drill hole with cement grout and then forcefully inserting the steel bar. Alternately, bricks were taken out and then filled with reinforced concrete as shown in Figure 9).

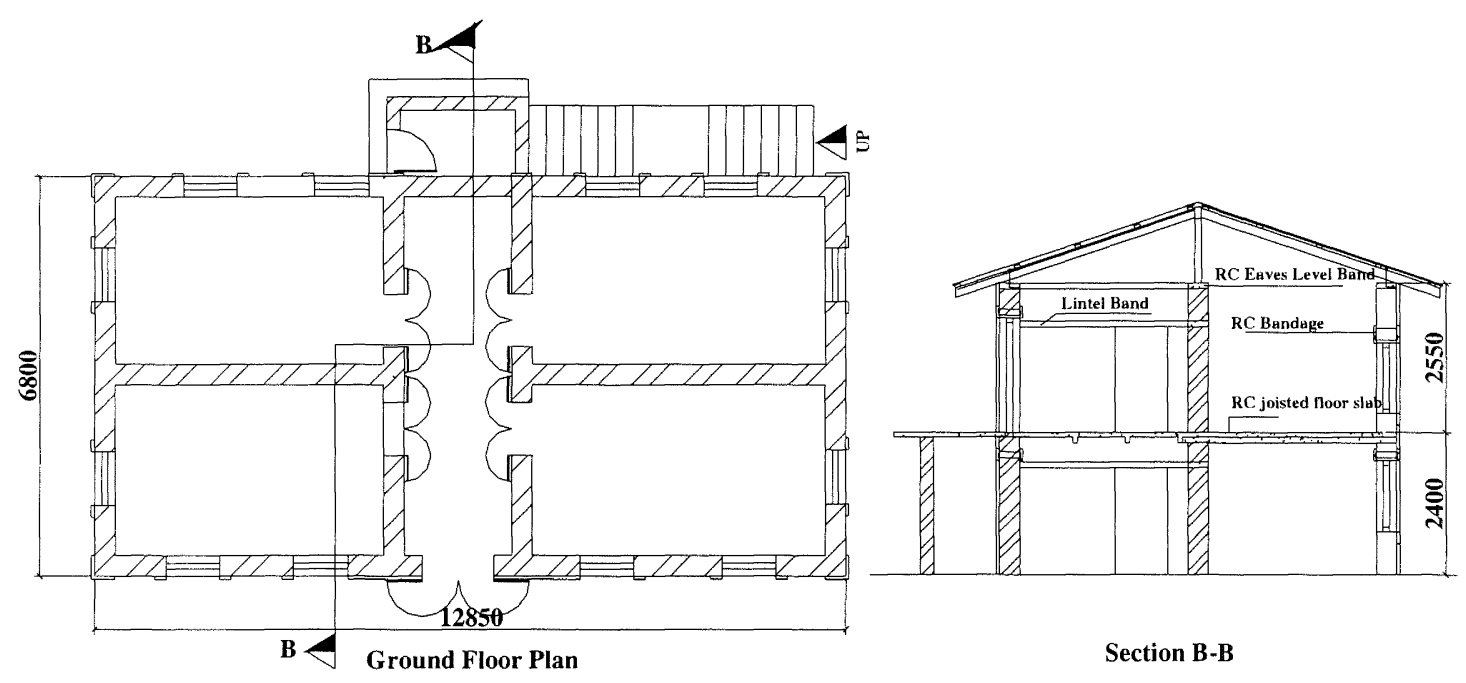

Figure 8: Improved Layout

The Splint and bandage system can be considered as an economic version of shotcrete jacketing where reinforcing bars are provided at most critical locations; i.e. wherever tensile stress can develop. Splints are vertical elements provided along the wall junction. In addition, openings were also surrounded by splints and bandages to prevent initiation of cracks from their corners (Figure 10). These were provided in the external face only (Figure 10). The goal was to supplement tensile strength in the vertical direction. Furthermore, the splints would also prevent the masonry being dislodged due to cracking. It is expected that the piers might suffer diagonal cracks but these cracks will be restrained from widening by vertical steel provided in the splits at the ends of the piers. 
The bandages are horizontal elements running around all the walls and building to integrate various walls together. The bandages were provided on both the faces of the walls just above the lintel level (Figure 11). These were connected to the masonry using staggered dowel bars with a spacing of $900 \mathrm{~mm}$. Furthermore, a RC band was put at the eaves level and gable top (Figure 8) wherever the roof was flexible.

The splints and bandages are the thin sections around $50 \mathrm{~mm}$ in thickness (Figure 10). To improve the bond with the walls, a 20 $\mathrm{mm}$ deep mortar was racked from the joints in brickwork before constructing the splint/ and bandage (Figure 9) where these would be constructed. Thereafter, a $15-20 \mathrm{~mm}$ thick layer of micro-concrete plaster was laid on the walls. The surface was kept very rough to bond second layer of mortar to. Reinforcing bars were fixed to the first layer of mortar with nails and then second layer of mortar was laid (Figure 11).

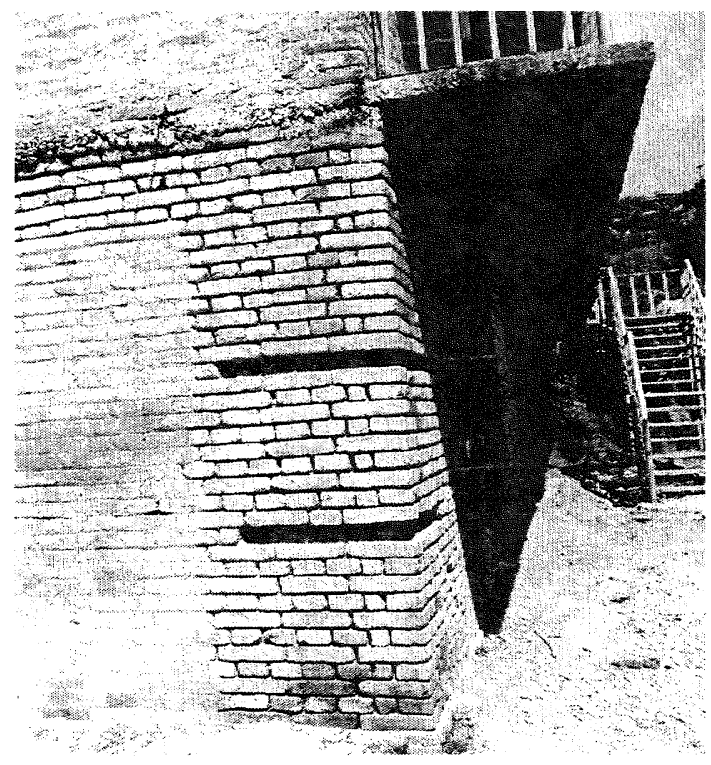

a) Before placing stitch

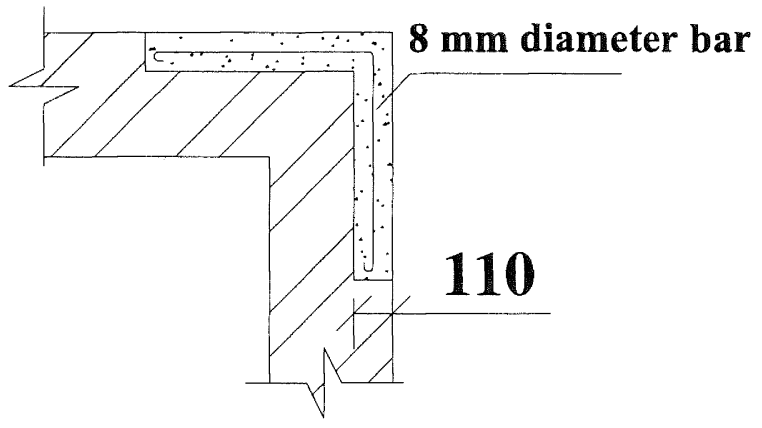

b) Stitch

Figure 9: Stitching of walls

To improve the floor diaphragm integrity the existing timber floor was replaced with a joisted RC floor. The joists and floor were well anchored to the wall by making recesses (Figure 8) in the wall. Either the flexible timber roofs were replaced with a RC slab or the integrity between different timber elements was improved by nailing and/or strapping. Integrity between the roof rafters and the walls was enhanced by anchoring rafters to walls (Fig 8). The diaphragm action of flexible roofs was improved by providing roof bracing.

Beam strengthening: The floor slab of one of the end rooms (size $5 \times 5.5 \mathrm{~m}$ ) of one of the retrofitted school building was sagging. Significant vibration could be felt even under normal walking. It was because of a very thin slab (about $75 \mathrm{~mm}$ ) being supported by a shallow beam ( $200 \mathrm{~mm}$ including slab). The beam was severely cracked at different locations. The quality of concrete was rather inferior, and the beam was not uniform in shape. Concrete cover was not consistently maintained, and brick fill was used in the beam and slab to save concrete.

In order to strengthen the beam, jacketing, propping it at the centre and post-stressing of the beam were considered as different options. Based on economic consideration, effectiveness and opportunity to develop the system, the beam was post-tensioned with two $20 \mathrm{~mm}$ diameter steel bars. Site- specific end anchorages were designed and simple jacks were developed for post-tensioning. The bars were anchored at the top of the beam at the ends (Figure 12). During post-stressing approximately 5 to $6 \mathrm{~mm}$ sag was recovered. After the implementation, no significant vibration was felt even when about 6-7 adults jumped on it. This low-cost method turned out to be very effective as no relaxation has been observed even after three years of service.

\section{CONCLUSION AND RECOMMENDATIONS}

Some low strength URM school buildings in Kathmandu Valley were retrofitted using cost-effective technologies to improve their seismic performance and to raise social awareness. The program was successful in transferring technology to local craftsmen who were quite keen to learn about the complete process and to adopt the technology. The authors felt that a large majority of the low strength URM school and residential buildings in Nepal can be strengthened using similar philosophy and techniques at an affordable cost.

As the authors could not access the existing theoretical background, if any, pertinent to this class of buildings, seismic strengthening was based upon identification of the most 
significant efficiencies and their amendment through simple calculations. However, in the absence of analytical or experimental knowledge to support the assumptions made in this work and the parameters used, the authors are not in a position to quantify improvements in seismic performance due to this retrofitting system on this class of buildings. The authors therefore, feel that further research is necessary to establish the seismic performance in general and the unknown parameters in particular of this retrofitting system.

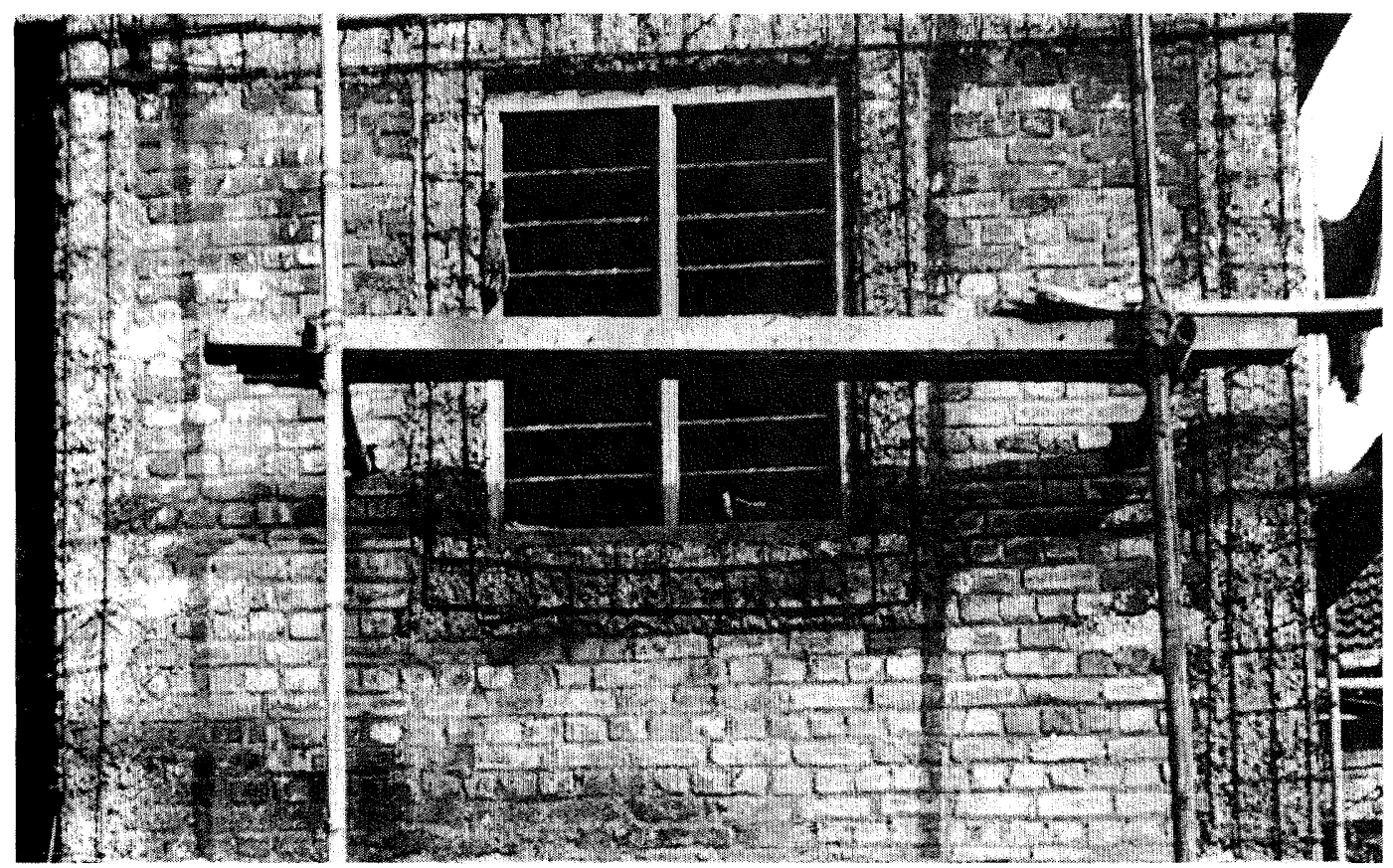

a) Splint and bandage under implementation

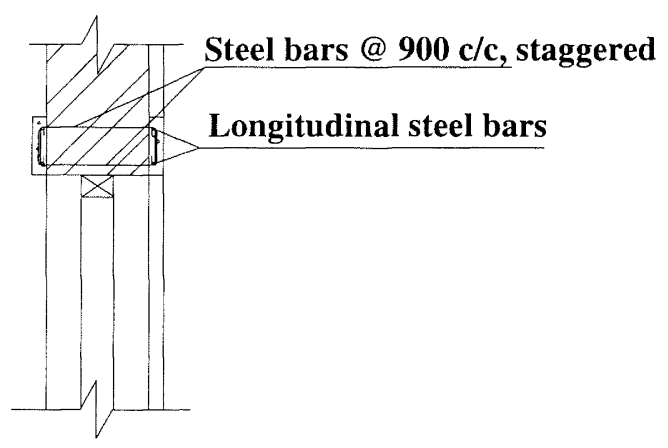

b) Bandage

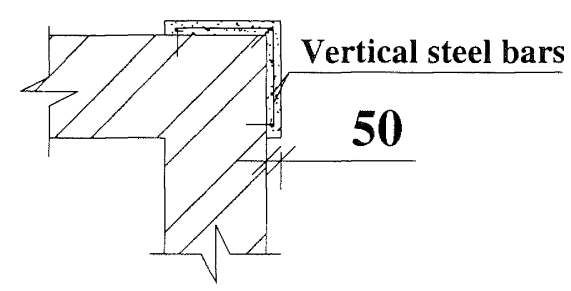

c) Splint

Figure 10: Construction of Splint, Bandage and Window Encasement

\section{ACKNOWLEDGEMENTS}

The authors are thankful to Prof. A. S. Arya, Emeritus Professor, Indian Institute of Technology-Roorkee, India for his guidance. We are thankful to Mr. S. B. Pradhanang, Mr. A. M. Dixit, Mr. M. Nakarmi, NSET-Nepal for their encouragement and continuous support. Special thanks are due to sponsors of this program for their support and sponsorship without which this programme would not have been materialized. We appreciate efforts of Dr. Rajesh Dhakal, Lecturer, and Dr. Bruce Deam, Lecturer, University of Canterbury for their co-operation in preparing this manuscript and editing respectively. We are thankful to Prof. John B. Mander for his kind remarks and encouragement. 


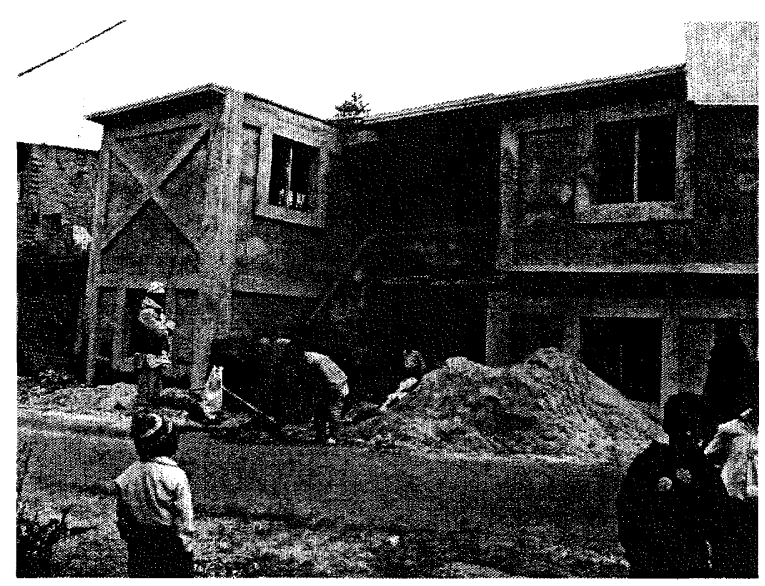

Figure 11: A Retrofitted School Building

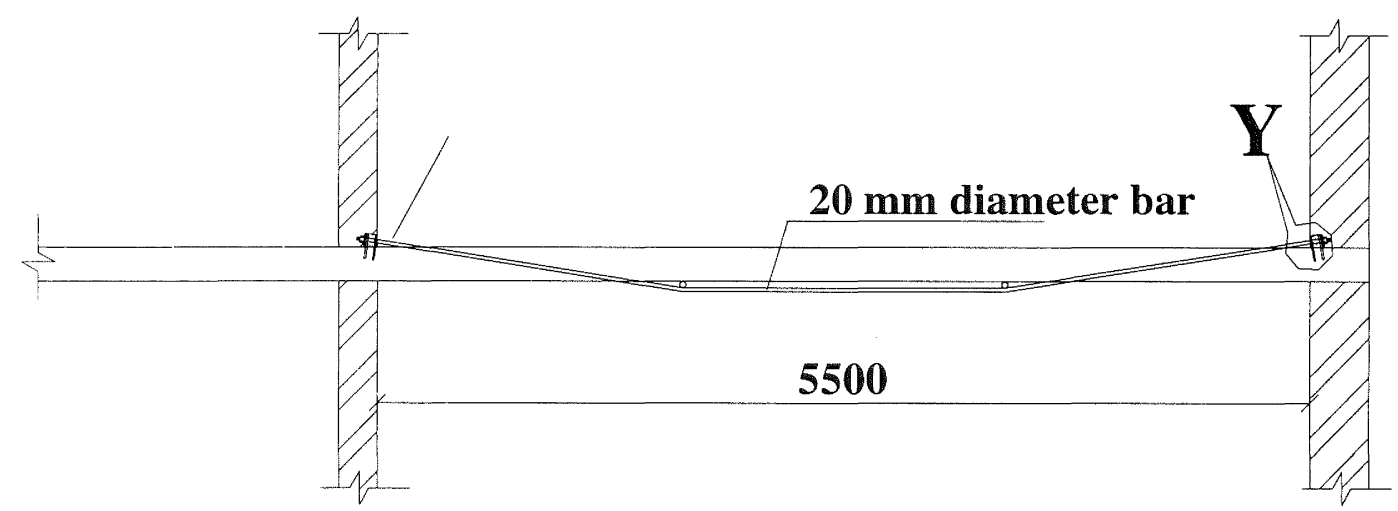

a) Longitudinal Section of Beam

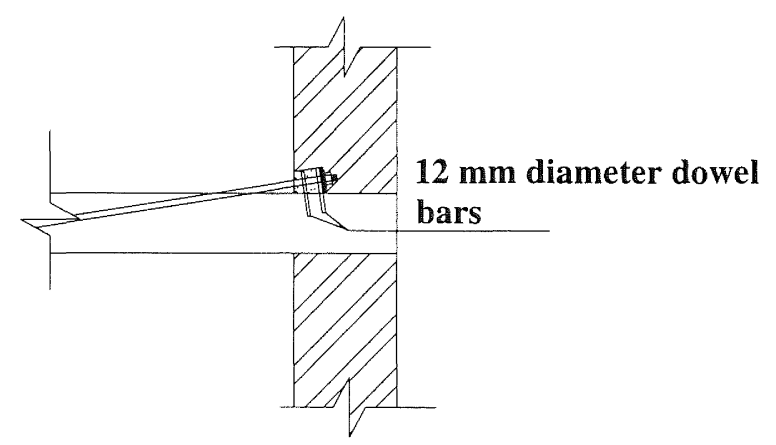

b) Detail-Y

Figure 12: Post stressing of beam 


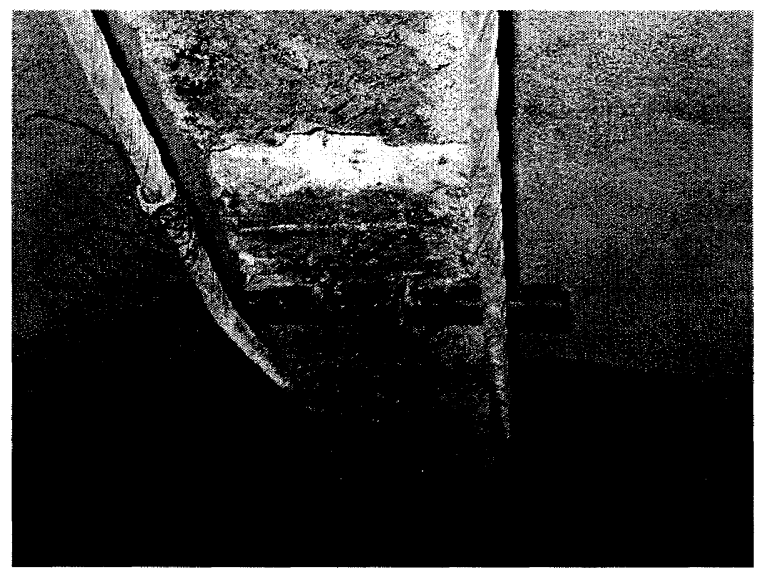

\section{c) System after implementation}

Figure 12 continued: Post stressing of beam

\section{REFERENCES}

1. Arya, A. S., (1987), Masonry and Timber Structures (including Earthquake Resistance Design), ISBN 8185240-05-1, Nem Chand \& Bros., Roorkee, UP, India.

2. Benedetti, D., Carydis, P., Pezzoli, P., (1998), "Shaking table test on 24 masonry buildings", Earthquake engineering and Structural Dynamics, Vol. 27, pp 67. 90 .

3. Bruneau, M, (1994), "State-of-the-Art report on seismic performance of Unreinforced Masonry Buildings", Jr. of Structural Engineering, Vol. 120, No. 1, pp 230-251.

4. Doherty, K. T., (2000), "An Investigation of the Weak Links in the Seismic Load Path of Unreinforced Masonry Buildings", A thesis submitted for Ph D, University of Adelaide, Australia.

5. Englekirk, R. E., Sabol, T. A., (1991), "Strengthening buildings to a life safety criterion", Earthquake Spectra, Vol. 7, No. 1, pp 81-87.

6. Fujiwara, T., Sato, T., Kubo, T., Murakami, H. O. (1989), "Reconnaissance Report on the 21 August 1988 Earthquake in The Nepal-India Border Region", Japanese Ministry of Education, Science and Culture (Grant No. 63115017), Japanese Group for the Study of Natural Disaster Science.

7. Karantoni, F. V., Fardis, M. N., (1992a), "Computed verses observed seismic response and damage of masonry buildings", Vol. 118, No. 7, pp 1804-1821.

8. Karantoni, F. V., Fardis, M. N., (1992b), "Effectiveness of seismic strengthening techniques for masonry buildings", Vol. 118, No. 7, pp 1884-1902.

9. MHPP, 1994, NBC 105-1994: "Seismic design of buildings in Nepal (Draft), Building Code Dev. Project Nepal", His Majesty's Government of Nepal, Ministry of housing and physical planning, UNCHS (UNDP Pro\# Nep.88.054-21.03), Kathmandu, Nepal.

10. MHPP, (1994), "Seismic Hazard Mapping and Risk assessment for Nepal, Building Code Dev. Project Nepal", His Government of Nepal, Ministry of housing and physical planning, UNCHS (UNDP Pro\# Nep.88.054-21.03), Kathmandu, Nepal.

11. NSET, (1999), "Reconnaissance Report on Chamoli Earthquake of 29 March 1999, India"; A joint study report by National Society for Earthquake TechnologyNepal, and Department of Earthquake Engineering, University of Roorkee, India http://www.adpc.net/audmp/projectoutputs/nepal/repor t-chamoli-eq-1.pdf

12. NSET, (2000), "Seismic Vulnerability of the school buildings of Kathmandu Valley and methods for reducing it" (unpublished), The Kathmandu Valley Earthquake Risk Management Project implemented by National Society for earthquake Technology, Kathmandu, Nepal.

13. NZSEE, (1995), "Draft guidelines for assessing and strengthening earthquake risk buildings", New Zealand Society of Earthquake Engineering, Wellington, NZ.

14. Qamaruddin, M., Arya, A. S., Chandra, B., (1985) "Dynamic response of multistoried brick buildings", Earthquake Engineering and Structural Dynamics, Vol. 13, No. 2, pp 135-150.

15. Qamaruddin, M., Chandra, B., (1991), "Behavior of unreinforced masonry buildings subjected to earthquakes", The Professional Jr. of Masonry Society, Vol. 9, No. 12, pp 47-55, The Masonry Society, USA. 